\title{
48. The Volcanological and Petrographical Note of the Taketomi Islet in the Kuriles.
}

\author{
By Hidezô Tanakadate, \\ Tohoku Imperial University, Sendai, \\ and \\ Hisashi Kuno, \\ Tokyo Imperial University. \\ (Comm. by H. YABE, M.I.A., April 12, 1985.)
}

Volcanology: As previously stated, Taketomi islet ${ }^{1)}$ consists of a small homate $117 \mathrm{~m}$ high above high tide and a lava plateau extending in its northeastern foot. According to the observations of one of the writers, the volcanological development of the islet may be summarized as follows:

(1) The stage of developing homate (XII, 1933-about III, 1934).

a. The eruption began with a strong volcanian outburst ejecting ash and preexisting lava fragments.

b. This stage was closed by a strombolian outbreak throwing out scoria and ash.

(2) The stage of lava flowing in the crater (about III-IV, 1934).

The lava ascended through the volcanic conduit and filled the crater bottom. This lava of a-a type flowed over the lowest part of the crater rim on the northeastern flank of the cone. Several cinder cones rose on the lava floor.

(3) The depression of the lava floor (IV-1934).

The central part of the lava floor gradually broke down about $15 \mathrm{~m}$ at most, leaving a narrow marginal belt of the original surface.

(4) The stage of the rejuvenated eruption (V-VI, 1934).

a. In the crater, the outbursts of the strombolian type recommenced on the depressed surface and produced several new cinder cones.

The lava issued, flowed on the floor and descended again on the northeastern flank of the volcano.

b. In the same time, outpour of lava took place on the sea floor at the northeastern foot of the cone and produced a lava plateau $300 \mathrm{~m}$ long and wide.

The surface of the plateau is slightly inclined towards the marginal part, and about $10 \mathrm{~m}$ high in average above the high tide.

The consistency in height of the vast plateau surface may be understood in assuming the lateral eruption to be caused by the pressure of the lava column in the central crater vent, and consequent gradual shifting of the positions of the lava pits on the sea bottom towards the northeast.

Petrography: Under the microscope, the lavas of Taketomi islet belong to a single kind of olivine-anorthite-basalt. Phenocrysts of 
plagicolase $\left(A n_{96}-A n_{92}\right.$ in the core of crystal, $A n_{\pi}$ in the margin) and olivine $\left(\beta=1.701\right.$ and $(-) 2 \mathrm{~V}=85^{\circ}$ in the core of crystal, $(-) 2 \mathrm{~V}=78^{\circ}$ in the margin) are always present, the former exceeding the latter in amount. Those of common augite are rarely present, while rhombic pyroxene is entirely absent. Groundmass is medium-grained and consists of plagioclase, augite $\left(\mathrm{Z} \wedge \mathrm{c}=46^{\circ}-50^{\circ},(+) 2 \mathrm{~V}=59^{\circ}-52^{\circ}\right)$, olivine $(-)$ $2 \mathrm{~V}=81^{\circ}$ ), magnetite, ilmenite, interstitial alkali-feldspar, and brown glass.

The basalts of Taketomi islet have a similar mineral composition to those of Alaid volcano. ${ }^{2}$

Chemical analyses of two specimens of the above mentioned basalts were undertaken by the Imperial Geological Survey, through the kindness of the Director, Mr. Nobuyasu Kanehara. The results are shown in the following table, together with the norms calculated from the former. The high content of alkalis in the analyses, especially in $\mathrm{K}_{2} \mathrm{O}$, may be correlated to the presence of alkali-feldspar in the modes. The excess silica which appears in the norms in spite of the presence of a considerable amount of olivine in the modes, may be occult in the glass base, since no silica minerals have been detected under the microscope.

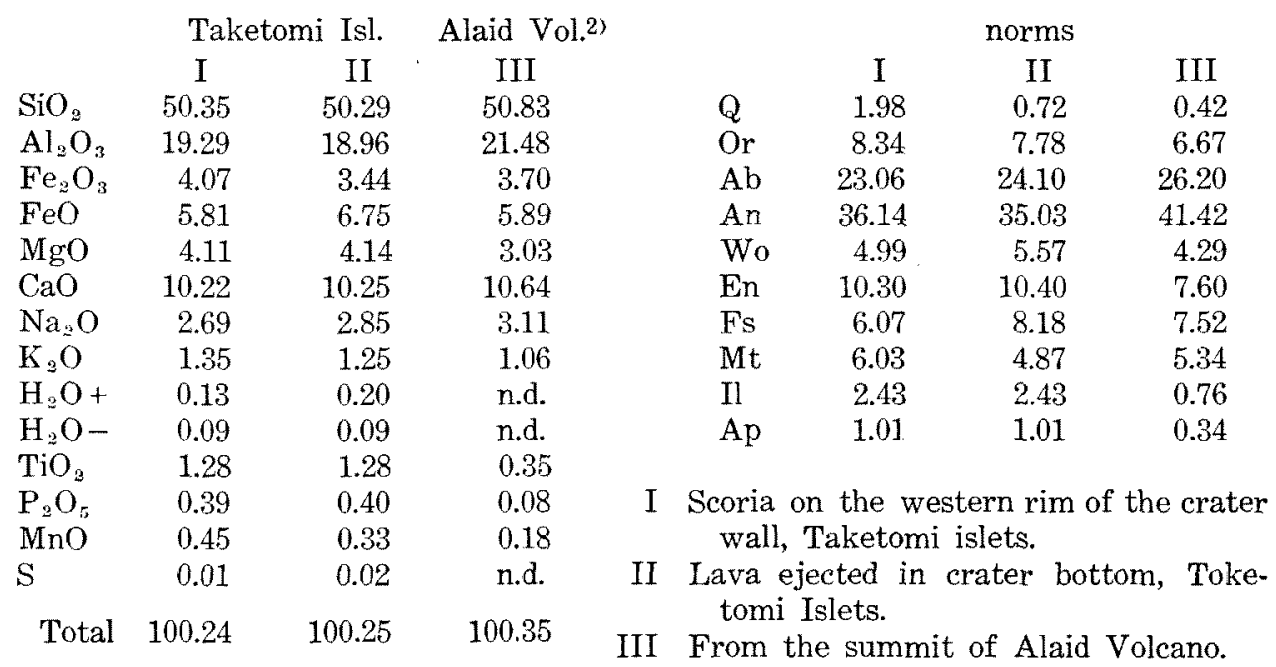

The lavas from the Taketomi Islet are similar in chemical composition to that of the Alaid Mountain, as the above table shows, and they are the most basic among the rocks, of the Japanese volcanoes, erupted in the recent time.

In certain petrographical characters the rocks from the Taketomi Islet and Alaid Volcano, resemble some of those from Idu and the adjacent districts, central Japan. Thus, the lavas from both districts are found to carry extremely calcic plagioclase as phenocrysts and also reveal excess silica in their norms.

But in some other petrographical and mineralogical characters they differ from each other. For example, the lavas from the Taketomi islet are richer in alkali and poorer in normative quartz than those from the Idu district. In mineralogical characters, there is also a contrast between the basalts from the two districts."

Final remark: Every recent eruption, as a rule, of the Japanese 
volcanoes manifests repeatedly the same characteristics since remote time.

Alaid volcano has many parasitic cones; some of them are arranged on a radial fissure, while the others are isolated. In both cases, the cone is homate of cinder and associated with a basaltic lava stream issued through the lateral opening. The Taketomi islet is merely a side cone of the latter case, exhibiting a characteristic which is the heredity for the recent lateral eruption of Alaid volcano, being formed after the above mentioned stages of development.

The lavas of Taketomi islet, though of extremely basic nature, belong to the a-a type; while those of Mihara-yama in Ôsima, etc., notwithstanding their richer contents of silica than the lavas of the Taketomi islet, belong to the pahoe-hoe type. This fact confirms that the two physical types of lava flows do not depend upon their chemical composition only. An a-a type of basic lava flows may perhaps be formed by submarine eruption.

\section{References.}

1) H. Tanakadate: Morphological Development of the Volcanic Islet Taketomi in the Kuriles. Proc. 10 (1934), 494.

2) J. Suzuki and Y. Sasa: Bull. Volc. Jap., Vol. 1, 1932, p. 22.

3) H. Tanakadate: Eruption types on Japanese Volcanoes in Recent Years etc. Proc. Forth Pacif. Sci. Congr., Java 1929, Vol. II B, 632-633. S. Kôzu: Report on the Great Eruption of Komagadake (in Japanese). Sci. Rep. Saitô-Hôonkwai, Sendai, 1932, p. 198.

\begin{tabular}{|c|c|c|c|c|c|c|c|}
\hline Volcano: & $\begin{array}{l}\text { Komaga- } \\
\text { dake }\end{array}$ & Tarumai & $\begin{array}{l}\text { Sakura- } \\
\text { zima }\end{array}$ & Asama & Tokati & Aso & $\begin{array}{l}\text { Miharayama } \\
\text { (Ốsima) }\end{array}$ \\
\hline $\begin{array}{l}\text { Month of } \\
\text { Eruption : }\end{array}$ & 1929-VI & 1909-IV & 1914-I & 1909 & $1926-V$ & $1929-\mathrm{V}$ & 1912-XII \\
\hline Material : & $\begin{array}{l}\text { Pumice } \\
\text { flow }\end{array}$ & $\begin{array}{l}\text { Slaggy } \\
\text { lava }\end{array}$ & $\begin{array}{l}\text { Slaggy } \\
\text { lava }\end{array}$ & Bomb & $\begin{array}{c}\text { Slaggy } \\
\text { lava }\end{array}$ & Scoria & Lava \\
\hline Analyst: & $\begin{array}{c}\text { Yagi, } \\
\text { Tôhoku } \\
\text { Imp. Univ. }\end{array}$ & \multicolumn{3}{|c|}{ Geological Survey of Japan } & $\begin{array}{l}\text { Tanaka, } \\
\text { Earthq. } \\
\text { Res. Inst. }\end{array}$ & \multicolumn{2}{|c|}{$\begin{array}{c}\text { Geological Survery } \\
\text { of Japan }\end{array}$} \\
\hline $\mathrm{SiO}_{2}$ & 61.47 & 60.93 & 60.59 & 59.76 & 53.93 & 53.52 & 51.13 \\
\hline $\mathrm{Al}_{2} \mathrm{O}_{3}$ & 15.44 & 16.46 & 17.77 & 16.90 & 18.39 & 18.67 & 17.75 \\
\hline $\mathrm{Fe}_{2} \mathrm{O}_{3}$ & 2.64 & 3.35 & 1.23 & 1.74 & 3.11 & 2.69 & 0.95 \\
\hline $\mathrm{FeO}$ & 4.91 & 5.94 & 5.59 & 5.46 & 6.21 & 5.93 & 11.58 \\
\hline $\mathrm{MgO}$ & 2.35 & 2.88 & 2.39 & 4.36 & 4.10 & 3.80 & 4.40 \\
\hline $\mathrm{CaO}$ & 6.60 & 7.87 & 6.34 & 8.66 & 8.83 & 9.27 & 10.83 \\
\hline $\mathrm{Na}_{2} \mathrm{O}$ & 4.79 & 1.44 & 3.04 & 1.05 & 2.40 & 2.90 & 1.30 \\
\hline $\mathrm{K}_{2} \mathrm{O}$ & 1.08 & 0.79 & 1.68 & 0.59 & 1.43 & 1.86 & 0.36 \\
\hline $\mathrm{H}_{2} \mathrm{O}+$ & 0.54 & - & 0.59 & 0.13 & 0.14 & 0.21 & 0.95 \\
\hline $\mathrm{H}_{2} \mathrm{O}-$ & - & - & - & - & 0.03 & 0.08 & - \\
\hline $\mathrm{TiO}_{2}$ & 0.49 & 0.42 & 0.71 & 1.23 & 1.25 & 0.85 & 1.01 \\
\hline $\mathrm{P}_{2} \mathrm{O}_{5}$ & 0.03 & 0.13 & 0.08 & Trace & 0.15 & 0.27 & Trace \\
\hline $\mathrm{MnO}$ & Trace & 0.55 & 0.24 & 0.38 & 0.19 & 0.14 & 0.25 \\
\hline $\mathrm{SO}_{3}$ & - & - & 0.23 & $\left(\mathrm{Mn}_{2} \mathrm{O}_{3}\right)$ & - & 一 & - \\
\hline $\mathrm{S}$ & - & 0.05 & - & - & - & - & - \\
\hline Total & 100.34 & 100.78 & 100.49 & 100.26 & 100.16 & 100.19 & 100.51 \\
\hline
\end{tabular}

4) Compare the mineral contents given in the preceding page to those cited in the following papers. H. Kuno and M. Sawatari : Jap. Journ. Geol. Geogr., Vol. 11, Nos. 3-4, 1934, p. 327 . S. Tsuboi and H. Kuno: Bull. Volc. Soc. Jap., Vol. 1, No. 1, 1932, p. 20. S. Tsuboi : Jap. Journ. Geol. Geogr., Vol. 10, 1932, p. 67. H. Kuno: Journ. Geol. Soc. Jap., Vol. 42, 1935, p. 39. H. Kuno: Bull. Earthq. Res. Inst., Tokyo Imp. Univ., Vol. 11, 1933, Pt. 2, p. 382. 